\title{
Varietal descriptors of sorghum varieties (Sorghum bicolor L. Moench) for registration and breeder's rights
}

\section{Caracterización varietal de dos variedades de sorgo (Sorghum bicolor L. Moench) con fines de registro y derecho de obtentor}

SANCHEZ-MARTINEZ José†*, AVENDAÑO-LOPEZ Adriana Natividad, PADILLA GARCIA José Miguel Padilla and ARELLANO-RODRIGUEZ Luis Javier

Instituto de Ciencia y Tecnología de Semillas INCITES, Departamento de Producción Agrícola, CUCBA, Universidad de Guadalajara, Jalisco, México

ID $1^{\text {st }}$ Author: José, Sánchez-Martínez / ORC ID: 0000002-1451-1149, Researcher ID Thomson: X-1133-2018, CVU CONACYT ID: 63408

ID $1^{\text {st }}$ Coauthor: Adriana Natividad, Avendaño-López/ORC ID: 0000-0003-1713-1165, Researcher ID Thomson: X-11052018, CVU CONACYT ID: 238209

ID $2^{\text {nd }}$ Coauthor: Jose Miguel, Padilla-Garcia

ID $3^{\text {rd }}$ Coauthor: Luis Javier, Arellano-Rodríguez / ORC ID: 0000-0002-3188-0245, CVU CONACYT ID: 65995

DOI: $10.35429 / J A N R E .2020 .7 .4 .1 .5$

Received September 25, 2020; Accepted November 10, 2020

\begin{abstract}
The registration and breeder's rights of varieties and hybrids in our country is very low compared to developed countries, however, the generation of this technology is frequent and they are marketed without an official registration. That is why the objective of this work is to characterize two precommercial varieties of sorghum, one with white grain and another with red grain in order to obtain the breeder's right. The characterization was carried out in the experimental fields of the University Center for Biological and Agricultural Sciences of the University of Guadalajara in the spring summer cycle of 2019 on two sowing dates. The methodology that was considered was the technical guide for varietal characterization approved by the International Union for the Protection of New Varieties of Plants UPOV. Central tendency analyzes were performed, the variation within materials was statistically analyzed using dispersion measures for grouped data such as range, variance, standard deviation, coefficient of variation and mean. Which provided the information for the decision of compliance with the main characteristics that allow each variety to be differentiated and to comply with the precepts that it is a new, homogeneous and stable variety.
\end{abstract}

Varietal character, Variety register, Varietal description

\begin{abstract}
Resumen
El registro y derechos de obtentor de variedades e híbridos en nuestro país es muy bajo comparado con los países desarrollados, sin embargo, la generación de esta tecnología es frecuente y se comercializan sin un registro oficial. Es por ello que el objetivo de este trabajo es caracterizar dos variedades precomerciales de sorgo una de grano blanco y otra de grano rojo con el fin de obtener el derecho de obtentor. La caracterización se realizó en los campos experimentales del Centro Universitario de Ciencias Biológicas y Agropecuarias de la Universidad de Guadalajara en el ciclo primavera verano de 2019 en dos fechas de siembra. La metodología que se consideró fue la guía técnica de caracterización varietal aprobada por la Unión Internacional para la Protección de las Obtenciones Vegetales UPOV. Se realizaron análisis de tendencia central, la variación dentro de materiales se analizó estadísticamente mediante las medidas de dispersión para datos agrupados como son el rango, varianza, desviación estándar, coeficiente de variación y media. Los cuales proporcionaron la información para la decisión de cumplimiento de los caracteres principales que permiten diferenciar cada variedad y dar cumplimento a los preceptos de que es una variedad nueva, homogénea y estable.
\end{abstract}

Carácter varietal, Registro de variedades, Descripción varietal

Citation: SANCHEZ-MARTINEZ José, AVENDAÑO-LOPEZ Adriana Natividad, PADILLA GARCIA José Miguel Padilla and ARELLANO-RODRIGUEZ Luis Javier. Varietal descriptors of sorghum varieties (Sorghum bicolor L. Moench) for registration and breeder's rights. Journal-Agrarian and Natural Resource Economics. 2020. 4-7: 1-5

\footnotetext{
* Correspondence to Author (email: adriana.avendano@academicos.udg.mx)
}

$\dagger$ Researcher contributing as first author. 


\section{Introduction}

The cultivation of sorghum is important in Mexico due to the area that is planted, occupying the fifth place worldwide, despite this, selfsufficiency is not achieved as it has to import around 700 thousand tons to cover the demand of 5 million 100 thousand tons (SADER, 2020). The area dedicated to cultivation oscillates in the million 200 thousand ha. That to cover the sowing, 16,800 tons of seed are required, the same as $95 \%$ if you have to import since you do not have the production of this important input by the companies that produce in Mexico. On the other hand, the research of the official body the National Institute of Agricultural and Livestock Forestry Research (INIFAP), as well as other institutions such as Universities have reduced their budgets for research and as a consequence the low generation of technology, in this case the generation of new varieties and hybrids of sorghum (Moreno GT and Hernández EL A 2011)

An improved variety is defined as the set of uniform plants, product of the application of a genetic improvement technique, with defined characteristics and that meets the condition of being different from others, stable and uniform, generally presenting higher yield potential, as well as various favorable conditions of quality, earliness, resistance to pests and diseases (Tadeo and Espinosa, 2004). According to Copeland and McDonald (2001), the seeds of improved varieties are the means to increase the yield and quality of crops, by serving as a bridge between genetic improvement (research) and the producer, the adoption of improved seeds allows reach competitive levels in production. Poey (1982), mentions that the differences between varieties are increasingly useful, which makes it necessary to identify the varietal characters in which they differ to determine their identity, uniformity and stability. The morphological or varietal description is a way of identifying the genetic purity, the degree of genetic advancement and the stability of the material; even define the degree of diversity between sorghum genotypes (Mohammed et al., 2015).

To carry out the varietal description, technical guides are proposed, which are issued by national and international organizations such as the National Seed Inspection and Certification Service (SNICS) and the International Union for the Protection of New Varieties of Plants (UPOV).
The guides include the set of descriptors and observations that allow characterizing a plant variety for its identification and distinction, which is an essential part for the registration of plant varieties or to request the issuance of a breeder's title before official agencies (SNICS, 2002; UPOV, 2012). The description of a variety must be made from the seed stage to maturity, for this an adequate sampling of plants must be achieved and their behavior must be observed in the appropriate environments; In this process, plants of other varieties and segregates of the same variety must be eliminated based on a reference pattern, which allows reliably to decide which phenotypes belong to the variety. This will allow the seed producer to maintain the genotypes that identify a variety after release (Poey, 1982).

Regarding the genetic quality of a plant variety, patterns of distinction, uniformity and stability are observed that identify it as having a high varietal purity, which is synonymous with a seed with quality in the genetic component. These patterns are based on morphological characteristics shown by the population, classified according to the form of evaluation in qualitative and quantitative characters (Kelly, 1988). Eberhart and Russell (1966) consider that a genotype is stable when the regression coefficient (bi) is equal to 1 and the regression deviations (S2di) equal to zero. Therefore, genotypes that do not interact with environmental factors will show zero slope and could be stable. Genotypes that show a medium response to environmental changes will have slopes equal to 1 , and the most stable genotype will be the one that shows the S2di value closest to zero.

The breeder's title grants temporary exclusivity in the use of the plant variety, thus recognizing the intellectual property of whoever develops a new plant variety. In order to obtain registration before the National Seed Inspection and Certification System (SNICS), it is necessary to have a varietal description to demonstrate that the genotype is new and different, this examination is carried out after the breeder has concluded his work of improvement. SNICS, 2019.

\section{Objectives}

Characterize the sorghum genotypes Xochitl and Violeta on two sowing dates

SANCHEZ-MARTINEZ José, AVENDAÑO-LOPEZ Adriana Natividad, PADILLA GARCIA José Miguel Padilla and ARELLANORODRIGUEZ Luis Javier. Varietal descriptors of sorghum varieties (Sorghum bicolor L. Moench) for registration and breeder's rights. Journal-Agrarian and Natural Resource Economics. 2020 
Compare the varietal descriptors of the two genotypes, using the qualitative and quantitative descriptors recommended by the International Union for the Protection of New Varieties of Plants (UPOV).

\section{Methodology}

The phenotypic characteristics of two new sorghum genotypes (Sorghum bicolor L. Moench) were described, which were generated in the genetic improvement program of the University Center for Biological and Agricultural Sciences CUCBA of the University of Guadalajara. Named Violeta and Xochitl. The evaluation was established in the experimental fields of Las Agujas, Zapopan, Jal. Under irrigation and seasonal conditions, two contrasting sowing dates were established. The crop was managed as commercial sowing; fertilization was 180-80-80 and density of 370,000 plants ha- 1 . A pre-emergent herbicide atrazine 3 L ha-1 was applied to control broadleaf grasses. The sample size used for each character was 20 plants per variety. The characterization of the varieties Xochitl and Violeta was carried out in the experimental fields of the University Center for Biological and Agricultural Sciences in the spring summer 2019 cycle, sowing 12 rows of $30 \mathrm{~m}$ long and $0.75 \mathrm{~m}$ wide and placing 25 seeds per meter with a population density of approximately 300 thousand plants per hectare. For each of the varieties with sowing date June 23, 2019 and replicating the lots on a second sowing date in the same experimental field on July 23, 2019. The agronomic management of land preparation and fertilization was the same for both sowing dates. To carry out the description, the technical guide for varietal characterization approved by the International Union for the Protection of New Varieties of Plants UPOV was used, which includes 36 characters between quantitative and qualitative. The data from the two planting dates were integrated to determine the total variation.

\section{Results}

The results of the description of the varieties allowed to establish the differences and similarities of the materials under study. Likewise, it was possible to identify the characters of the phenotypes in which a greater interaction with the environment was expressed, through the coefficient of variation that was presented in the analysis.

\begin{tabular}{|c|c|c|c|}
\hline Characteristic & Level & $\begin{array}{l}\text { Viol } \\
\text { et }\end{array}$ & $\begin{array}{c}\text { Xoch } \\
\text { itl }\end{array}$ \\
\hline $\begin{array}{l}\text { Seedling: coleoptile } \\
\text { anthocyanin pigmentation }\end{array}$ & $\begin{array}{l}\text { Absent or very } \\
\text { weak }\end{array}$ & $\mathrm{x}$ & $\mathrm{x}$ \\
\hline $\begin{array}{l}\text { Leaf: anthocyanin } \\
\text { pigmentation of the blade }\end{array}$ & $\begin{array}{l}\text { Absent or very } \\
\text { weak }\end{array}$ & $\mathrm{x}$ & $\mathrm{x}$ \\
\hline Plant: number of tillers & $\begin{array}{l}\text { Null or very } \\
\text { low }\end{array}$ & $\mathrm{x}$ & $\mathrm{x}$ \\
\hline Leaf: intensity of green color & Medium & $\mathrm{x}$ & $\mathrm{x}$ \\
\hline Leaf: midrib color & Light green & $\mathrm{x}$ & $\mathrm{x}$ \\
\hline $\begin{array}{l}\text { Leaf: discolored area of the } \\
\text { midrib }\end{array}$ & Little & $\mathrm{x}$ & $\mathrm{x}$ \\
\hline \multirow{2}{*}{$\begin{array}{l}\text { Plant: time of appearance of } \\
\text { panicles }\end{array}$} & Half & & $\mathrm{x}$ \\
\hline & Late & $\mathrm{x}$ & \\
\hline $\begin{array}{l}\text { Glume: anthocyanin } \\
\text { pigmentation }\end{array}$ & $\begin{array}{l}\text { Absent or very } \\
\text { weak }\end{array}$ & $\mathrm{x}$ & $\mathrm{x}$ \\
\hline $\begin{array}{l}\text { Stigma: anthocyanin } \\
\text { pigmentation }\end{array}$ & $\begin{array}{l}\text { Absent or very } \\
\text { weak }\end{array}$ & $\mathrm{x}$ & $\mathrm{x}$ \\
\hline $\begin{array}{l}\text { Stigma: anthocyanin } \\
\text { pigmentation }\end{array}$ & White & & $\mathrm{x}$ \\
\hline $\begin{array}{l}\text { Stigma: anthocyanin } \\
\text { pigmentation }\end{array}$ & Medium yellow & $\mathrm{x}$ & \\
\hline Stigma: color & Short & $\mathrm{x}$ & $\mathrm{x}$ \\
\hline \multirow{2}{*}{$\begin{array}{l}\text { Flower with pedicel: flower } \\
\text { length }\end{array}$} & Short & & $\mathrm{x}$ \\
\hline & Median & $\mathrm{x}$ & \\
\hline Flower: self-fertility & high & $\mathrm{x}$ & $\mathrm{x}$ \\
\hline $\begin{array}{l}\text { Glume: color at the end of } \\
\text { flowering }\end{array}$ & Medium green & $\mathrm{x}$ & $\mathrm{x}$ \\
\hline \multirow{2}{*}{$\begin{array}{l}\text { Absent or very weak } \\
\text { Absent or very weak }\end{array}$} & Half & $\mathrm{x}$ & \\
\hline & Dense & & $\mathrm{x}$ \\
\hline Null or very low & $\begin{array}{l}\text { Absent or very } \\
\text { short }\end{array}$ & $\mathrm{x}$ & $\mathrm{x}$ \\
\hline Medium & Oranged Red & $\mathrm{x}$ & $\mathrm{x}$ \\
\hline Light green & Median & $\mathrm{x}$ & $\mathrm{x}$ \\
\hline Little & Medium & $\mathrm{x}$ & $\mathrm{x}$ \\
\hline \multirow{2}{*}{$\begin{array}{l}\text { Half } \\
\text { Late }\end{array}$} & Medium & & $\mathrm{x}$ \\
\hline & Long & $\mathrm{x}$ & \\
\hline Absent or very weak & Width & $\mathrm{x}$ & $\mathrm{x}$ \\
\hline Absent or very weak & Median & $\mathrm{x}$ & $\mathrm{x}$ \\
\hline \multirow{2}{*}{$\begin{array}{l}\text { White } \\
\text { Medium yellow }\end{array}$} & Short & & $\mathrm{x}$ \\
\hline & Long & $\mathrm{x}$ & \\
\hline Short & Medium & $\mathrm{x}$ & $\mathrm{x}$ \\
\hline Short & \begin{tabular}{|l} 
Dense \\
\end{tabular} & $\mathrm{x}$ & $\mathrm{x}$ \\
\hline Median & Half & $\mathrm{x}$ & $\mathrm{x}$ \\
\hline \multirow{2}{*}{$\begin{array}{l}\text { high } \\
\text { Medium green }\end{array}$} & Medium yellow & & $\mathrm{x}$ \\
\hline & Light yellow & $\mathrm{x}$ & \\
\hline \multirow{2}{*}{$\begin{array}{l}\text { Absent or very weak } \\
\text { Absent or very weak }\end{array}$} & Short & $\mathrm{x}$ & \\
\hline & Median & & $\mathrm{x}$ \\
\hline \multirow[t]{2}{*}{ Null or very low } & $\begin{array}{l}\text { Yellowish } \\
\text { white }\end{array}$ & & $\mathrm{x}$ \\
\hline & Light brown & $\mathrm{x}$ & \\
\hline \multirow{2}{*}{$\begin{array}{l}\text { Light green } \\
\text { Little }\end{array}$} & Little & $\mathrm{x}$ & \\
\hline & Medium & & $\mathrm{x}$ \\
\hline \multirow{2}{*}{$\begin{array}{l}\text { Half } \\
\text { Late }\end{array}$} & Oval & $\mathrm{x}$ & \\
\hline & Circular & & $\mathrm{x}$ \\
\hline Absent or very weak & Median & $\mathrm{x}$ & \\
\hline Absent or very weak & Big & & $\mathrm{x}$ \\
\hline \multirow[b]{2}{*}{ Medium yellow } & $\begin{array}{l}\text { Null or very } \\
\text { low }\end{array}$ & & $\mathrm{x}$ \\
\hline & Medium & $\mathrm{x}$ & \\
\hline \multirow[t]{2}{*}{ Short } & $\begin{array}{l}\text { Vitreous in its } \\
3 / 4 \text { parts }\end{array}$ & & $\mathrm{x}$ \\
\hline & $\begin{array}{l}\text { Farinaceous in } \\
\text { its } 3 / 4 \text { parts }\end{array}$ & $\mathrm{x}$ & \\
\hline Median & Yellow & $\mathrm{x}$ & $\mathrm{x}$ \\
\hline high & Insensitive & $\mathrm{x}$ & $\mathrm{x}$ \\
\hline
\end{tabular}

Table 1 Varietal descriptors evaluated in sorghum varieties, during 2019

SANCHEZ-MARTINEZ José, AVENDAÑO-LOPEZ Adriana Natividad, PADILLA GARCIA José Miguel Padilla and ARELLANORODRIGUEZ Luis Javier. Varietal descriptors of sorghum varieties (Sorghum bicolor L. Moench) for registration and breeder's rights. Journal-Agrarian and Natural Resource Economics. 2020 
Regarding the characters that presented a greater variation measured by C.V. Table 2 presents the values for the Violeta variety. The most variable characters are those that experience the greatest interaction with the environment.

\begin{tabular}{|l|r|}
\hline \multicolumn{1}{|c|}{ Character } & C V \% \\
\hline 1. coleoptile pigmentation & 30 \\
\hline 3. No. of stains & 30 \\
\hline 4. sheet int. Colour & 15 \\
\hline 5.central nerve color & 11 \\
\hline 6. zone desc. Central & 17 \\
\hline 10. this color & 28 \\
\hline 11. stigma length & 34 \\
\hline 12.Long flower & 21 \\
\hline 14. glume color & 12 \\
\hline 15. panicle density & 11 \\
\hline 16. lemma log. Edge & 57 \\
\hline 17. anther dry color & 11 \\
\hline 25. dens. maturity & 15 \\
\hline 27.gluma mad color. & 10 \\
\hline 28. glua long & 9 \\
\hline 32. germ brand size & 9 \\
\hline 34. endosperm type & 16 \\
\hline
\end{tabular}

Table 2 Percentage values of the Coefficient of variation presented by the characters in the Xochitl variety

The values presented were within the range of 9 to $57 \%$, unlike the Violeta variety where coefficient of variation values were presented within the range of values of 5 to $40 \%$.

\begin{tabular}{|l|r|}
\hline \multicolumn{1}{|c}{ Character } & C.V \% \\
\hline 1.colleoptile pigmentation seedling & 40 \\
\hline 4. Sheet int. Green color & 14 \\
\hline 5.central nerve color & 12 \\
\hline 6. Zone desc. Central & 14 \\
\hline 10. This color & 5 \\
\hline 14. Glume color & 7 \\
\hline 15. Panicle density & 9 \\
\hline 17. Anther dry color & 7 \\
\hline 20. Log sheet. & 6 \\
\hline 22. Panicle length & 9 \\
\hline 23 long. Neck & 5 \\
\hline 24. Lon rami primaries & 9 \\
\hline 25. Dens. Maturity & 6 \\
\hline 26. Wide part position & 11 \\
\hline 27. Gluma mad color. & 8 \\
\hline 28. Glume long & 26 \\
\hline 29. Grain color & 2 \\
\hline 31. Dors view form. & 14 \\
\hline 32. Germ brand size & 11 \\
\hline 35. Vitria endos color & \\
\hline
\end{tabular}

Table 3 Characters of the Violeta variety that presented greater variation
These results, in addition to describing the materials under study, are the basis to establish whether it is necessary to carry out a purification in the materials or to establish the ranges of variation that will be considered within range due to the genetic composition of the materials.

\section{Conclusions}

Based on the evaluated variables, it is concluded that the varieties are different from each other,

The varietal description of the sorghum varieties is the technical document that will integrate the application for registration of the evaluated materials

\section{References}

Copeland, L. O., y M. B. McDonald. 2001. Principles of Seed Science and Technology. 4th ed. Kluwer Academic Publishers. Massachusetts, USA. 467 p.

Eberhart, S. A. and Russel, W. A. 1966. Stability parameters in comparing varieties. Crop Sci. 6:36-40.

Kelly, A. F. 1988. Seed production of agricultural crops. Ed. Longman Scientific \& Technical. New York, USA. $226 \mathrm{p}$

Mohammed, R., Are, A.K., Bhavanasi, R., Munghate, M.S., Kavi-Kishor, P.V., and Sharma, A.S. 2015. Quantitative genetic analysis of agronomic and morphological traits in sorghum, Sorghum bicolor. Frontiers Plant Science 6:1-17. Poey D., F. 1982. La descripción varietal: fundamentos para el control de la pureza genética de las semillas. Memorias curso avanzado sobre producción de semilla básica del 27 de Abril al 27Mayo. CIAT, Cali Colombia. $41 \mathrm{p}$.

Servicio Nacional de Inspección y Certificación de Semillas (SNICS) 2002. Guía técnica para la descripción varietal en maíz (Zea mays L.). SAGARPA-SNICS. D. F., México. 20 p.

Tadeo, R. M. y Espinosa, C. A. 2004. Producción y tecnología de semillas. Ingeniería Agrícola. Universidad Nacional Autónoma de México. Cuautitlán Izcalli, México. 106 p. 
Unión Internacional para la Protección de las Obtenciones Vegetales (UPOV). 1991. Convenio internacional para la protección de las obtenciones vegetales. Ginebra, Suiza. 28 p.

UPOV (International Union for the Protection of New Varieties of Plant). 2012. Sorghum. TG/122. UPOV Code: SRGHM. Sorghum ssp. Guidelines for the conduct of tests for distinctness, uniformity and stability. $48 \mathrm{p}$. 